\title{
1,4-Naphthoquinone Analogues: Potent Antibacterial Agents and Mode of Action Evaluation
}

\author{
Palanisamy Ravichandiran ${ }^{1}\left(\right.$, , Sunirmal Sheet ${ }^{2}$, Dhanraj Premnath ${ }^{3}$, Ae Rhan Kim ${ }^{4, *}$ \\ and Dong Jin Yoo $1, *$ (i)
}

1 Department of Life Science, Department of Energy Storage/Conversion Engineering of Graduate School and Hydrogen and Fuel Cell Research Center, Chonbuk National University, Jeollabuk-do 54896, Korea; ravichandru55@gmail.com

2 Department of Forest Science and Technology, College of Agriculture and Life Sciences, Chonbuk National University, 567 Baekje-daero, Deokjin-gu, Jeonju-si 561-756, Jeollabuk-do, Korea; sunirmal.micro@gmail.com

3 Department of Biotechnology, Karunya Institute of Technology and Science, School of Agriculture and Biosciences, Karunya Nagar, Coimbatore 641114, Tamil Nadu, India; prems.bioinfo@gmail.com

4 R\&D Center for CANUTECH, Business Incubation Center, Department of Bioenvironmental Chemistry, Chonbuk National University, Jeollabuk-do 54896, Korea

* Correspondence: canutech@hanmail.net (A.R.K.); djyoo@jbnu.ac.kr (D.J.Y.); Tel.: +82-(0)63-270-3608/+82-(0)10-2110-2328 (D.J.Y.); Fax: +82-(0)63-270-3909 (D.J.Y.)

Received: 15 March 2019; Accepted: 4 April 2019; Published: 11 April 2019

check for updates

\begin{abstract}
Naphthoquinones have antibacterial activity and are a promising new class of compound that can be used to treat bacterial infections. The goal was to improve effective antibacterial agents; therefore, we synthesized a new class of naphthoquinone hybrids, which contain phenylamino-phenylthio moieties as significant counterparts. Compound 4 was modified as a substituted aryl amide moiety, which enhanced the antibacterial activity of earlier compounds 3 and 4 . In this study, five bacterial strains Staphylococcus aureus (S. aureus), Listeria monocytogenes (L. monocytogenes), Escherichia coli (E. coli), Pseudomonas aeruginosa (P. aeruginosa) and Klebsiella pneumoniae (K. pneumoniae) were used to evaluate the antibacterial potency of synthesized naphthoquinones using the minimal inhibitory concentration (MIC) method. Most of the studied naphthoquinones demonstrated major antibacterial activity with a MIC of $15.6 \mu \mathrm{g} / \mathrm{mL}-500 \mu \mathrm{g} / \mathrm{mL}$. Selected compounds (5a, $\mathbf{5} \mathbf{f}$ and $\mathbf{5 x}$ ) were studied for the mode of action, using intracellular ROS generation, determination of apoptosis by the Annexin V-FITC/PI assay, a bactericidal kinetic study and in silico molecular modelling. Additionally, the redox potentials of the specified compounds were confirmed by cyclic voltammetry (CV).
\end{abstract}

Keywords: quinones; ROS generation; apoptosis; kinetic study

\section{Introduction}

Bacterial infections have become the most significant threat to global human health since the Second World War, and active antibiotics have been used to cure bacterial diseases. However, the constant use of antibiotics has induced bacterial resistance, which is currently a severe problem worldwide. Therefore, the design and evaluation of active antimicrobial agents with high selectivity, less toxicity and unique novel mechanisms have become a major goal [1].

Apoptosis is a programmed cell death of any infected cells, which can be induced by morphological or molecular signalling mechanisms. During oral treatment of different kinds of bacterial infections, apoptosis works to kill the harmful or affected cells and maintain homeostasis in the human body. Recent studies have demonstrated that, if the chemical compound can target the infection-inducing bacterial cells, the generation of reactive oxygen species (ROS) is a significant process in apoptosis [2]. 
Bacterial cells are more susceptible to ROS-generating chemical agents. Hence, ROS-generating agents could provide a possible approach for advancing antibacterial drugs with high therapeutic value [3].

1,4-Naphthoquinones are widely available in many naturally occurring alkaloids and have been classified as potential antibacterial candidates $[4,5]$. The mechanism of these antibacterial agents involves enhanced ROS generation and is followed by apoptotic cell death [6,7]. A number of compounds with a 1,4-naphthoquinone moiety can activate noticeable biological inhibitions such as antimicrobial [8], anticancer [9], antitubercular [10], antimalarial [11] and trypanocidal [12] activities. Due to the ability to generate ROS, naphthoquinone analogues are extremely cytotoxic to the infected cells and can restrict cellular enzymes, which are responsible for apoptosis and cell growth [13]. Consequently, these compounds have been evaluated as primary models for developing and improving clinically available antibacterial drugs. However, although the mode of action for most antibacterial drugs is known, the specific mechanism of action has not yet been elucidated.

We recently reported the synthesis and biological evaluation of new naphthoquinone derivatives as potential anticancer and antimicrobial agents $[14,15]$. The molecules were previously studied for anticancer activity, and an apoptotic mechanism in cancer cells was reported [16]. In this study, we evaluated the in vitro antibacterial effects of 1,4-naphthoquinone derivatives that contained phenylamino-phenylthio moieties as significant counterparts. We further investigated the effects of most active naphthoquinones (5a, $\mathbf{5} \mathbf{f}$ and $\mathbf{5 x}$, Figure 1 ) for ROS generation and apoptosis induction in Escherichia coli (E. coli). In addition, a bactericidal time-kill kinetic study, in silico molecular docking and redox property by cyclic voltammetry $(\mathrm{CV})$ study were also analyzed.<smiles>O=C(Nc1ccc(S(=O)(=O)c2ccc(NC3=C(Sc4ccccc4)C(=O)c4ccccc4C3=O)cc2)cc1)c1ccccc1</smiles>

5a, MIC $=15.6 \mu \mathrm{g} / \mathrm{mL}$

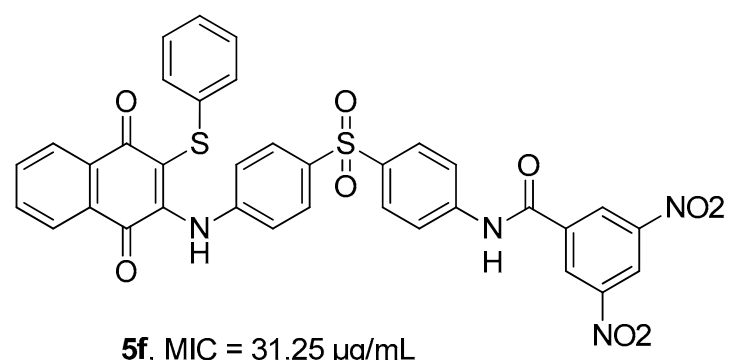

5f, $\mathrm{MIC}=31.25 \mu \mathrm{g} / \mathrm{mL}$<smiles>O=C1C(Cl)=C(Nc2ccc(S(=O)(=O)O)cc2)C(=O)c2ccccc21</smiles>

$5 x, M I C=31.25 \mu \mathrm{g} / \mathrm{mL}$

where, MIC = Minimum Inhibition Concentration

Figure 1. The structures of most active naphthoquinones from the current library.

\section{Results and Discussion}

\subsection{Chemistry}

For synthesis, experimental details and complete results and discussion of compounds 3-5aa, kindly refer to our previous report [16].

\subsection{Biology}

\subsubsection{In Vitro Antibacterial Activity}

Compounds 3-5aa (Figure 2) were studied for in vitro antibacterial activity in two Gram-positive bacteria (Staphylococcus aureus (S. aureus) and Listeria monocytogenes (L. monocytogenes)) and three 
Gram-negative bacteria (Escherichia coli (E. coli), Pseudomonas aeruginosa (P. aeruginosa) and Klebsiella pneumoniae (K. pneumoniae)). Streptomycin was used as a positive antibacterial drug control, and MIC values are given in Table 1.<smiles>Nc1ccc(S(=O)(=O)c2ccc(NC3=C(Cl)C(=O)c4ccccc4C3=O)cc2)cc1</smiles>

3<smiles>[R]c1ccccc1C(=O)Nc1ccc(S(=O)(=O)c2ccc(NC3=C(Sc4ccccc4)C(=O)c4ccccc4C3=O)cc2)cc1</smiles>

$5 a \mathrm{R}=\mathrm{H}$

$5 \mathrm{~b} R=\mathrm{F}$

$5 \mathrm{c} \mathrm{R}=\mathrm{Br}$<smiles>[R]c1ccc(C(=O)Nc2ccc(S(=O)(=O)c3ccc(NC4=C(Sc5ccccc5)C(=O)c5ccccc5C4=O)cc3)cc2)cc1</smiles>

$5 \mathrm{~h} \mathrm{R}=\mathrm{OMe}$

5i $\mathrm{R}=\mathrm{Me}$

5j $\mathrm{R}=\mathrm{C}\left(\mathrm{CH}_{3}\right)_{3}$

$5 \mathrm{k} R=\mathrm{F}$<smiles>O=C(Cc1ccc(Cl)cc1)Nc1ccc(S(=O)(=O)c2ccc(NC3=C(Sc4ccccc4)C(=O)c4ccccc4C3=O)cc2)cc1</smiles>

$5 q$<smiles>[R]C(=O)Nc1ccc(S(=O)(=O)c2ccc(NC3=C(Sc4ccccc4)C(=O)c4ccccc4C3=O)cc2)cc1</smiles>

$5 \mathrm{~s} \mathrm{R}=\mathrm{CH}_{2} \mathrm{CH}_{3}$

$5 \mathrm{t} \mathrm{R}=\mathrm{Me}$

5u $\mathrm{R}=\mathrm{CH}(\mathrm{Cl})_{2}$<smiles>Nc1ccc(S(=O)(=O)c2ccc(NC3=C(Sc4ccccc4)C(=O)c4ccccc4C3=O)cc2)cc1</smiles>

4<smiles>[R]c1cc([R])cc(C(=O)Nc2ccc(S(=O)(=O)c3ccc(NC4=C(Sc5ccccc5)C(=O)c5ccccc5C4=O)cc3)cc2)c1</smiles>

$$
5 \text { e } \mathrm{R}^{1}=\mathrm{Cl}, \mathrm{R}^{2}=\mathrm{Cl}
$$$$
5 f R^{1}=N_{2}, R^{2}=N_{2}
$$$$
5 \mathrm{~g} \mathrm{R}^{1}=\mathrm{NO}_{2}, \mathrm{R}^{2}=\mathrm{H}
$$<smiles></smiles>

$50 X=0$

$5 p X=S$<smiles>O=C1C(Nc2ccc(S(=O)(=O)c3ccc(NC(=O)c4cccc5ccccc45)cc3)cc2)=C(Sc2ccccc2)C(=O)c2ccccc21</smiles>

$5 r$<smiles>[R][X]c1ccc(NC2=C(Cl)C(=O)c3ccccc3C2=O)cc1</smiles><smiles>[R]c1ccc(NC2=C(Sc3ccccc3)C(=O)c3ccccc3C2=O)cc1</smiles>

$5 \mathrm{v}=3-\mathrm{OH}$

$5 \mathrm{wR}=4-\mathrm{Me}$

$5 \times \mathrm{R}=4-\mathrm{SO}_{3} \mathrm{H}$

Figure 2. Structure of naphthoquinones (3-5aa) used in the present study. 
Most of the synthesized naphthoquinone derivatives (3-5aa) showed moderate to good antibacterial activity against $S$. aureus and E. coli. However, these naphthoquinones had less activity toward bacterial pathogens L. monocytogenes, P. aeruginosa and K. pneumoniae.

Table 1. In vitro antibacterial activity of 1,4-naphthoquinones (3-5aa) expressed as MIC ( $\mu \mathrm{g} / \mathrm{mL})$.

\begin{tabular}{|c|c|c|c|c|c|}
\hline \multicolumn{6}{|c|}{ MIC $(\mu \mathrm{g} / \mathrm{mL})$} \\
\hline \multicolumn{3}{|c|}{ Gram-positive } & \multicolumn{3}{|c|}{ Gram-negative } \\
\hline Compd. & $\begin{array}{c}\text { S. aureus } \\
\text { (ATCC 23235) }\end{array}$ & $\begin{array}{l}\text { L. monocytogenes } \\
\text { (ATCC 19111) }\end{array}$ & $\begin{array}{c}\text { E. coli } \\
\text { (KCTC 2571) }\end{array}$ & $\begin{array}{c}\text { P. aeruginosa } \\
\text { (KACC 10259) }\end{array}$ & $\begin{array}{c}\text { K. pneumoniae } \\
\text { (ATCC BAA-2342) }\end{array}$ \\
\hline 3 & 500 & 250 & NA & 500 & 250 \\
\hline 4 & 125 & 500 & 250 & 250 & 125 \\
\hline $5 a$ & 125 & 125 & 15.6 & 125 & 250 \\
\hline $5 b$ & 500 & 500 & 500 & 500 & 500 \\
\hline $5 c$ & 500 & 250 & 250 & NA & 500 \\
\hline $5 d$ & 125 & 500 & 500 & 500 & 500 \\
\hline $5 e$ & 62.5 & 500 & 250 & 500 & 250 \\
\hline $5 f$ & 31.25 & 125 & 31.25 & 62.5 & 62.5 \\
\hline $5 g$ & 500 & 250 & 500 & 250 & 250 \\
\hline $5 \mathrm{~h}$ & 125 & 500 & 250 & 250 & 500 \\
\hline $5 i$ & 62.5 & 500 & 500 & 250 & 500 \\
\hline $5 j$ & 250 & 125 & 250 & 62.5 & 250 \\
\hline $5 \mathrm{k}$ & 62.5 & 500 & 500 & 500 & 500 \\
\hline 51 & 125 & 500 & 125 & 125 & 500 \\
\hline $5 \mathrm{~m}$ & 250 & NA & 250 & 125 & 250 \\
\hline $5 n$ & 125 & 500 & 250 & 500 & NA \\
\hline 50 & 500 & NA & 62.5 & 250 & 125 \\
\hline $5 p$ & 250 & NA & NA & NA & 250 \\
\hline $5 q$ & 62.5 & 500 & 250 & 500 & 250 \\
\hline $5 r$ & 250 & 500 & 250 & 125 & 250 \\
\hline $5 s$ & 500 & 500 & 62.5 & 500 & 500 \\
\hline $5 t$ & 500 & 250 & NA & 500 & 500 \\
\hline $5 u$ & 500 & NA & 62.5 & 250 & 250 \\
\hline $5 v$ & 500 & 250 & NA & 500 & 500 \\
\hline $5 w$ & 500 & 62.5 & NA & 500 & 250 \\
\hline $5 x$ & 125 & 250 & 31.25 & 500 & 125 \\
\hline $5 y$ & 250 & NA & 62.5 & 250 & 125 \\
\hline $5 z$ & 250 & 500 & 62.5 & 250 & 125 \\
\hline 5 аa & 250 & 500 & 500 & 250 & 250 \\
\hline $\operatorname{Str}^{[*]}$ & 7.70 & 15.61 & 1.90 & 7.81 & 7.83 \\
\hline
\end{tabular}

At first, compounds 3 and 4 were prepared as model compounds to evaluate antibacterial activity in Gram-positive and Gram-negative bacteria. The studied compounds showed a 64-fold weaker antibacterial potency compared to streptomycin (1.9-15.6 $\mu \mathrm{g} / \mathrm{mL})$. Next, varieties of substituted aromatic and aliphatic acid chlorides were introduced to compound 4 with the primary amine to create the substituted amide moiety; this resulted in more potent antibacterial agents compared with the parent compounds 3 and 4 . These results indicated that the formation of the amide moiety with various length of acid chlorides (5a, 5f, 5i, 5j, $\mathbf{5 0}$ and $\mathbf{5 q}$ ) significantly enhanced the antibacterial activity compared with the earlier compounds 3 and 4 . Most of the synthesized compounds were most active against the Gram-positive bacteria $S$. aureus $(\mathbf{5 e}, \mathbf{5} \mathbf{f}, \mathbf{5 i}, \mathbf{5 k}$ and $\mathbf{5 q}$ ) with activity that ranged from 31.25 to $62.5 \mu \mathrm{g} / \mathrm{mL}$, and Gram-negative bacteria E. coli (5a, 5f, 5o, $5 \mathbf{s}$ and $5 \mathbf{u}$ ), with MIC values of 31.25-62.5 $\mu \mathrm{g} / \mathrm{mL}$. All studied compounds (3-5u) showed the weakest antibacterial activity against L. monocytogenes, P. aeruginosa and K. pneumoniae. In addition, compounds 5v-5aa were also evaluated for in vitro antibacterial activity; compound $5 \mathbf{w}$ showed significant activity against L. monocytogenes $(62.5 \mu \mathrm{g} / \mathrm{mL})$, and the other compounds $\mathbf{5 x}, \mathbf{5 y}$ and $\mathbf{5 z}$ showed potential activity against E. coli (31.25 to 
$62.5 \mu \mathrm{g} / \mathrm{mL}$ ). From the present library (3-5aa), none of the compounds exhibited superior activity to the streptomycin positive control.

Based on these results, the structure-activity relationship (SAR) for the synthesized compounds (3-5aa) was investigated. The introduction of thiophenol into compound 3 showed moderate antibacterial activity compared with the starting compound 3. Interestingly, the introduction of a substituted amide moiety into compound 4 , with substituted acid chlorides, resulted in increased antibacterial activity. Compound $\mathbf{5 f}$ containing a 3,5-dinitro aryl moiety was found to have enhanced activity against all five bacterial pathogens studied. Similarly, compounds grafted with electron donating/electronegative functional groups showed better antibacterial activity $(\mathbf{5} \mathbf{a}, \mathbf{5 e}, \mathbf{5 i}, \mathbf{5 k}, \mathbf{5 j}, \mathbf{5} \mathbf{q}$, $5 s, 5 x, 5 y$ and $5 z$ ) than the parent compounds 3 and 4 . However, compounds that were constructed with a bulky moiety or electron-withdrawing (except $5 \mathbf{f}$ ) functional groups showed poor inhibitory potencies $(5 \mathbf{g}, 5 \mathbf{n}$ and $5 \mathbf{r})$.

\subsubsection{Bactericidal Time-Kill Kinetic Study}

The three most active compounds $\mathbf{5 a}, \mathbf{5} \mathbf{f}$ and $\mathbf{5} \mathbf{x}$ were selected from the obtained in vitro antibacterial activity of compounds 3-5aa for further investigation of the mode of action. The degree and rate of bactericidal properties must be evaluated first to determine the antibacterial potency of antimicrobial agents. A bactericidal time-kill kinetic study is the most convenient method to determine the degree and rate at which a compound inhibits bacteria [17]. Therefore, we first determined the bactericidal kinetic activity of $\mathbf{5 a}, \mathbf{5 f}$ and $\mathbf{5 x}$ with a time-kill assay to $E$. coli, with the corresponding MIC $(15.60 \mu \mathrm{g} / \mathrm{mL}$, $31.25 \mu \mathrm{g} / \mathrm{mL}$ and $31.25 \mu \mathrm{g} / \mathrm{mL}$, respectively). E. coli cells at the initial stage were counted as $10^{6.1} \mathrm{CFU} / \mathrm{mL}$, and survival started to decrease after $4 \mathrm{~h}$ of treatment and dropped to $10^{\circ} \mathrm{CFU} / \mathrm{mL}$ after $24 \mathrm{~h}$. In addition, compound $\mathbf{5 f}$ showed good bactericidal kinetic ability compared with $\mathbf{5 a}$ and $\mathbf{5 x}$. These results clearly show time-dependent bactericidal activity in all three compounds (Figure 3).

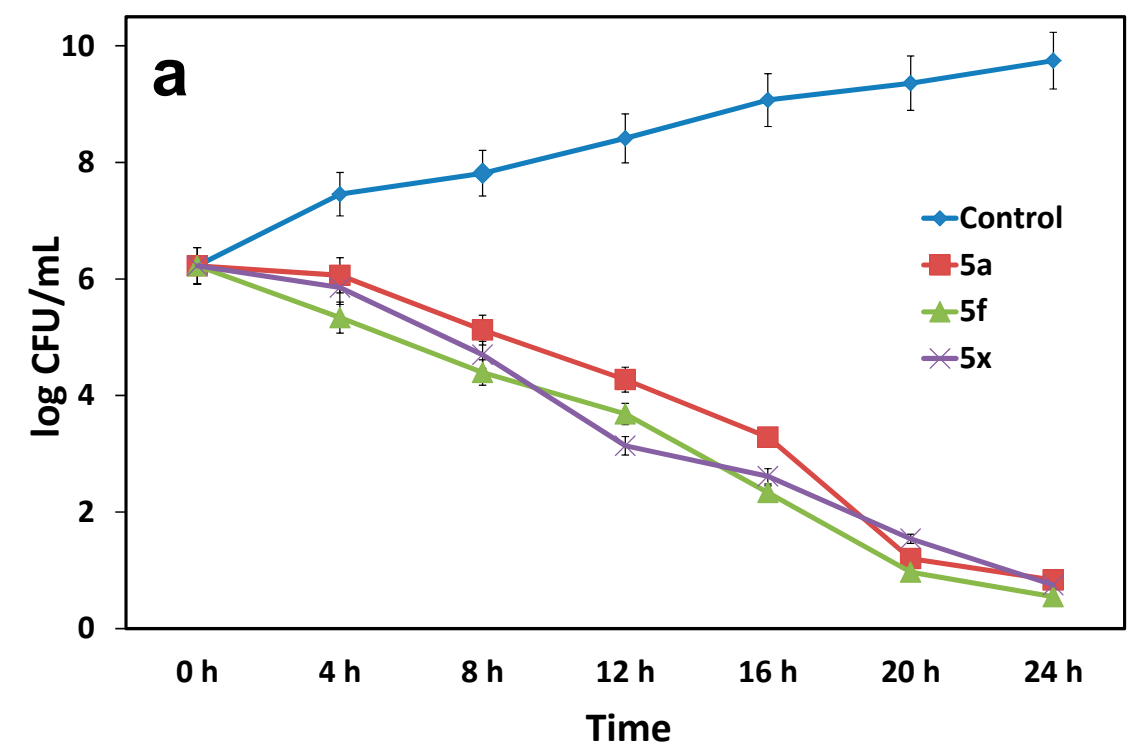

Figure 3. Cont. 


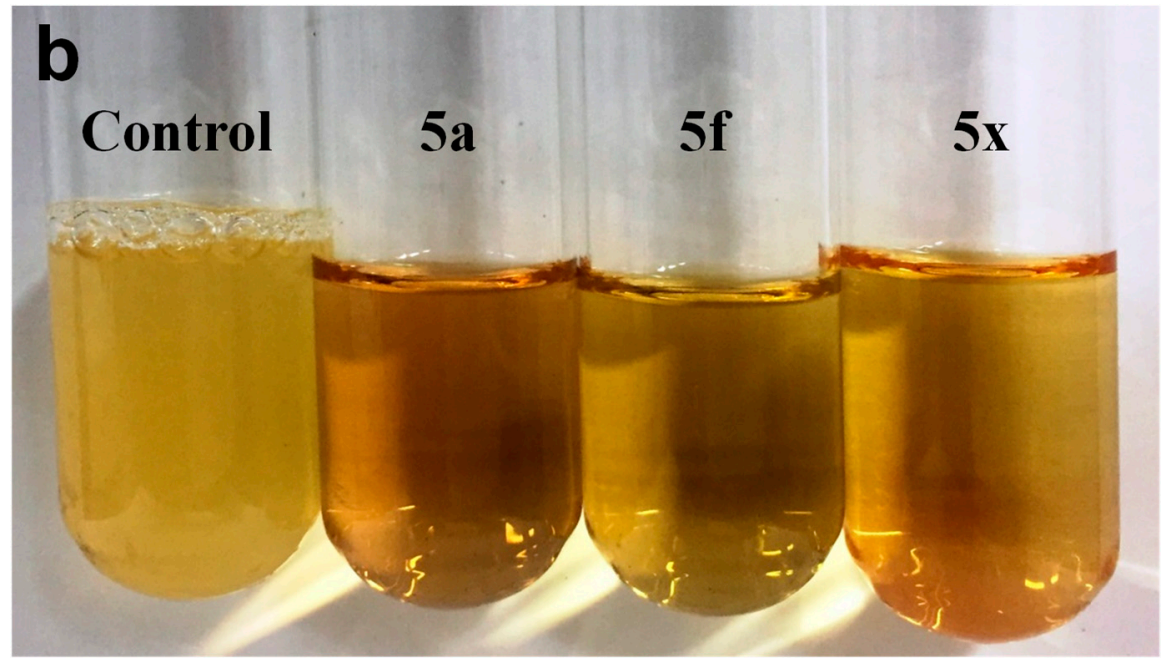

Figure 3. (a) Time-dependent bactericidal activity of compounds $\mathbf{5 a}, \mathbf{5} \mathbf{f}$ and $\mathbf{5 x}$ to E. coli. All the experiments performed in triplicates and are given the mean \pm standard deviation of colony-forming units per milliliter (S.D of CFU/mL). (b) Images show E. coli, after $24 \mathrm{~h}$ treatment with compounds 5a, $5 f$ and $5 x$.

Analysis of Minimum Bactericidal Concentration (MBC)

Next, the minimum bactericidal concentration (MBC) of compounds $\mathbf{5 a}, \mathbf{5} \mathbf{f}$ and $\mathbf{5 x}$ against $E$. coli was studied. The MIC and MBC are two key considerations to estimate the ratio of MBC/MIC. All the results are furnished in Table 2, the outcome of these results shows MIC ranges from $15.60 \mu \mathrm{g} / \mathrm{mL}$ to $31.25 \mu \mathrm{g} / \mathrm{mL}$. Based on the results obtained, the characteristics of the compounds against $E$. coli can be determined. If MBC/MIC ratio is 1 or 2 the compounds are bactericidal. If MBC/MIC ratio is 4 to 16 the compounds are bacteriostatic, or else if $\mathrm{MBC} / \mathrm{MIC}>32$, the compounds are tolerant to the bacterial strain. Therefore, the obtained results clearly indicate, the compounds $\mathbf{5 a}$ and $\mathbf{5 x}$ are bactericidal and compound $\mathbf{5} \mathbf{f}$ is bacteriostatic in nature towards E.coli [18].

Table 2. MBC and MBC/MIC data of compounds $\mathbf{5 a}, \mathbf{5 f}$ and $\mathbf{5 x}$ against E. coli.

\begin{tabular}{cccc}
\hline Compound & $\begin{array}{c}\text { MIC } \\
(\mu \mathrm{g} / \mathrm{mL})\end{array}$ & $\begin{array}{c}\text { MBC } \\
(\boldsymbol{\mu g} / \mathbf{m L})\end{array}$ & MBC/MIC Ratio \\
\hline $\mathbf{5 a}$ & 15.60 & 31.2 & 2.0 \\
$\mathbf{5 f}$ & 31.25 & 93.75 & 3.0 \\
$\mathbf{5 x}$ & 31.25 & 62.5 & 2.0 \\
\hline
\end{tabular}

\subsubsection{Naphthoquinone-Generated ROS Detection}

We then studied the intracellular ROS generation of the three selected compounds toward the Gram-negative bacteria E. coli. Enhancement of ROS level in cells is a significant requirement for the antibacterial activity of 1,4-naphthoquinones [19]. Thus, we evaluated the ROS generation of compounds $\mathbf{5 a}, \mathbf{5 f}$ and $\mathbf{5 x}$ in E. coli by DCFH-DA fluorescent dye staining. Treatment of E. coli with $\mathbf{5 a}$, $5 f$ and $5 x$ generated bursts of ROS, as shown by the increasing green fluorescence intensity due to compound-induced ROS production (Figure 4). Compounds $\mathbf{5 a}, \mathbf{5} \mathbf{f}$ and $\mathbf{5} \mathbf{x}$ showed equal fluorescence intensity to the antibacterial drug streptomycin. These results indicate that the antibacterial activity of $5 a, 5 f$ and $5 x$ impacts the oxidative stress of ROS. 


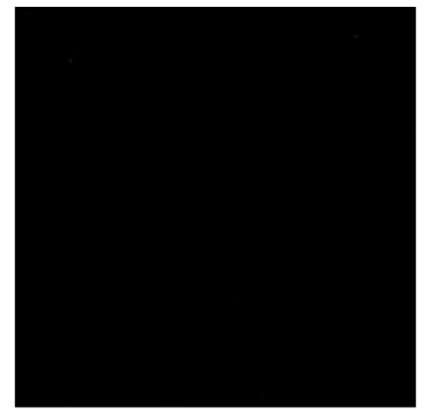

Control

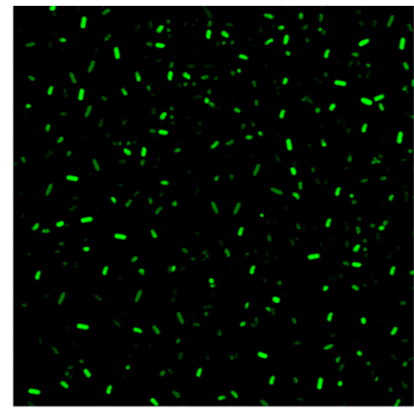

Streptomycin $(1.90 \mu \mathrm{g} / \mathrm{mL})$

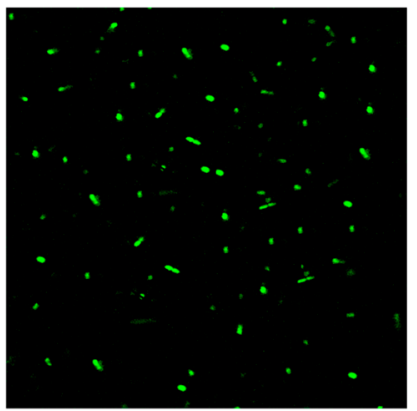

$5 \mathrm{a}(15.60 \mu \mathrm{g} / \mathrm{mL})$

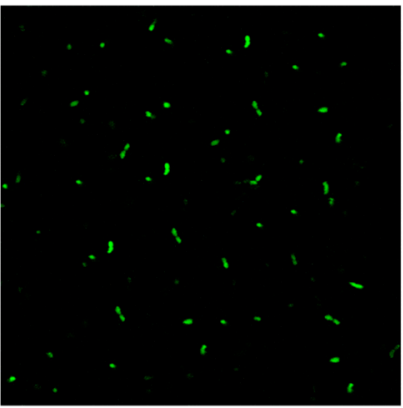

$5 f(31.25 \mu \mathrm{g} / \mathrm{mL})$

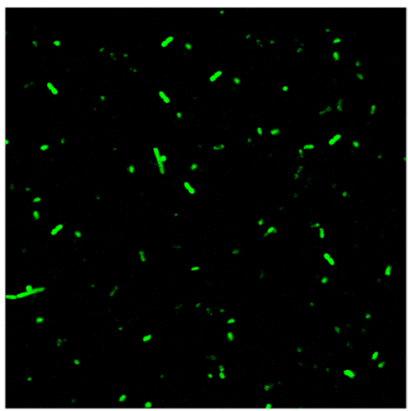

$5 \times(31.25 \mu \mathrm{g} / \mathrm{mL})$

Figure 4. Detection of ROS generation of compounds $\mathbf{5 a}, \mathbf{5 f}$ and $\mathbf{5 x}$ in E. coli.

\subsubsection{Apoptosis by Annexin V-FITC/PI Double Staining Assay}

Further, apoptosis-induced effects of the selected compounds $\mathbf{5 a}, \mathbf{5} \mathbf{f}$ and $\mathbf{5 x}$ were evaluated by the Annexin V-FITC/PI double staining assay. Bacterial cells (E. coli) were treated with the respective MIC of 5a, 5f and 5x for 12 h; then cells were harvested, washed with PBS solution and stained with Annexin-V and PI. The total percentage of apoptotic cells was evaluated by flow cytometry. As shown in Figure 5, the treatment of E. coli with $\mathbf{5 a}$ and $5 \mathbf{x}$ at $15.60 \mu \mathrm{g} / \mathrm{mL}$ and $31.25 \mu \mathrm{g} / \mathrm{mL}$, respectively, was identified in $91.1 \%$ and $83.2 \%$ of late apoptotic cells compared with $15.4 \%$ in control cells. However, compound 5f showed death in $30.4 \%$ of cells in early apoptosis and $45.19 \%$ in late apoptosis. These results indicate that compounds $\mathbf{5 a}, \mathbf{5} \mathbf{f}$ and $\mathbf{5 x}$ induce early apoptosis and late apoptosis in E. coli at specified concentrations. Therefore, the apoptotic effects of compounds occur in the order $5 \mathbf{a}>\mathbf{5 x}>\mathbf{5 f}$. 

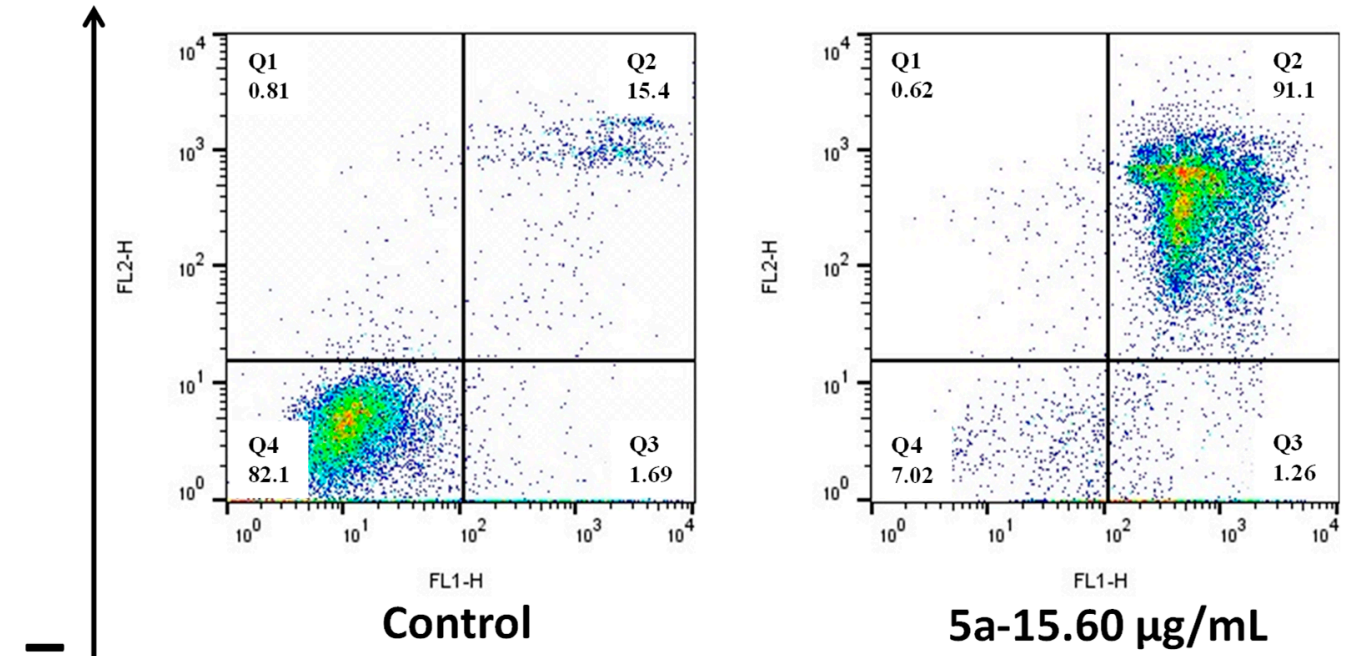

$\overline{\mathbf{a}}$

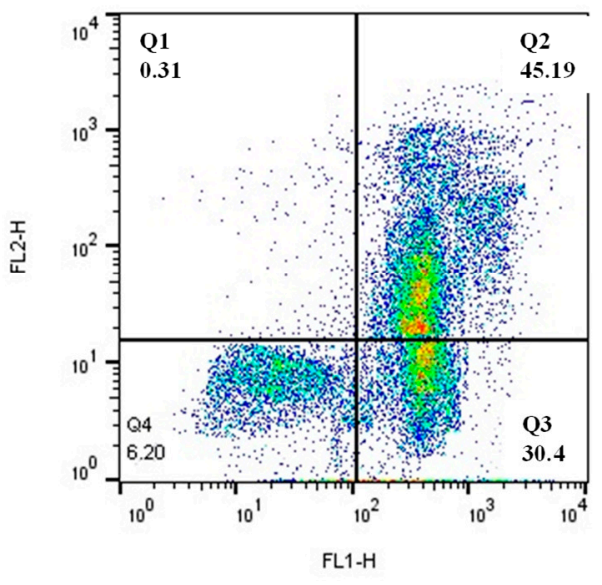

$5 f-31.25 \mu \mathrm{g} / \mathrm{mL}$

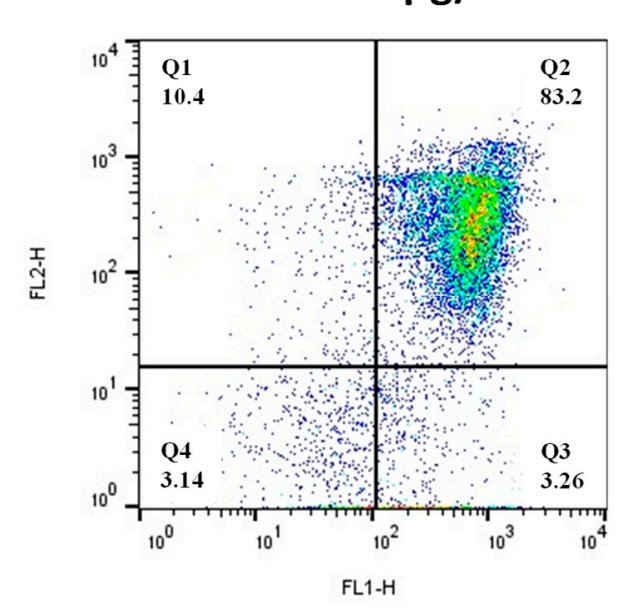

$5 \mathrm{x}-31.25 \mu \mathrm{g} / \mathrm{mL}$

\section{Annexin V}

Figure 5. Apoptosis evaluation was performed by Annexin V-FITC/PI(Annexin V-Fluorescein isothiocyanate/ Propidium Iodide (FITC/PI)) double staining assay.

\subsubsection{Molecular Docking Study}

Many clinically evaluated drugs do not reach end users due to poor pharmacokinetics or intolerable side effects [20]. Consequently, in silico docking can be used to estimate the distribution, metabolism, absorption, toxicity and excretion, which may be a significant approach that can reduce these risks. In proteins, DmsD is a type of cytoplasmic chaperone that plays a significant role in blocking redox proteins from early transport. Therefore, the molecular interaction of compound $5 \mathbf{a}$ was studied against the crystal structure of the E. coli DmsD protein (PDB ID: 3CW0), and the results are depicted in Figure 6.

A number of clinically evaluated drugs could not reach end users due to the unfortunate pharmacokinetics or intolerable side effects. Consequently, in silico docking approaches to estimate the distribution, metabolism, absorption, toxicity and excretion may be a significant approach to reduce these risks. In proteins, DmsD is a kind of cytoplasmic chaperones that play a significant role in stopping redox proteins from early transport. Therefore, the molecular interaction of compound $\mathbf{5 a}$ was studied against the crystal structure of E. coli DmsD protein (PDB ID: 3CW0) and the obtained results are depicted in Figure 6.

The in silico molecular docking results of $5 \mathbf{a}$ indicated that the molecular interactions with the biological model showed an active site of the $3 \mathrm{CW} 0$ protein with a docking score of $-2.636 \mathrm{kcal} / \mathrm{mol}$. 
The results indicate that a ligand was bound in the cavity of the protein molecule. The superposition of $\mathbf{5 a}$ and amino acid residues of the 3CW0 protein are evident and depicted in Figure 6b,c. Compound 5a was exposed to a hydrogen-bonding interaction with the corresponding active site of ARG A15 along with $\pi-\pi$ stacking. These relationships of 3CW0 and 5a might explain the experimental antibacterial activity; however, additional investigations are warranted to further elucidate the mode of action.

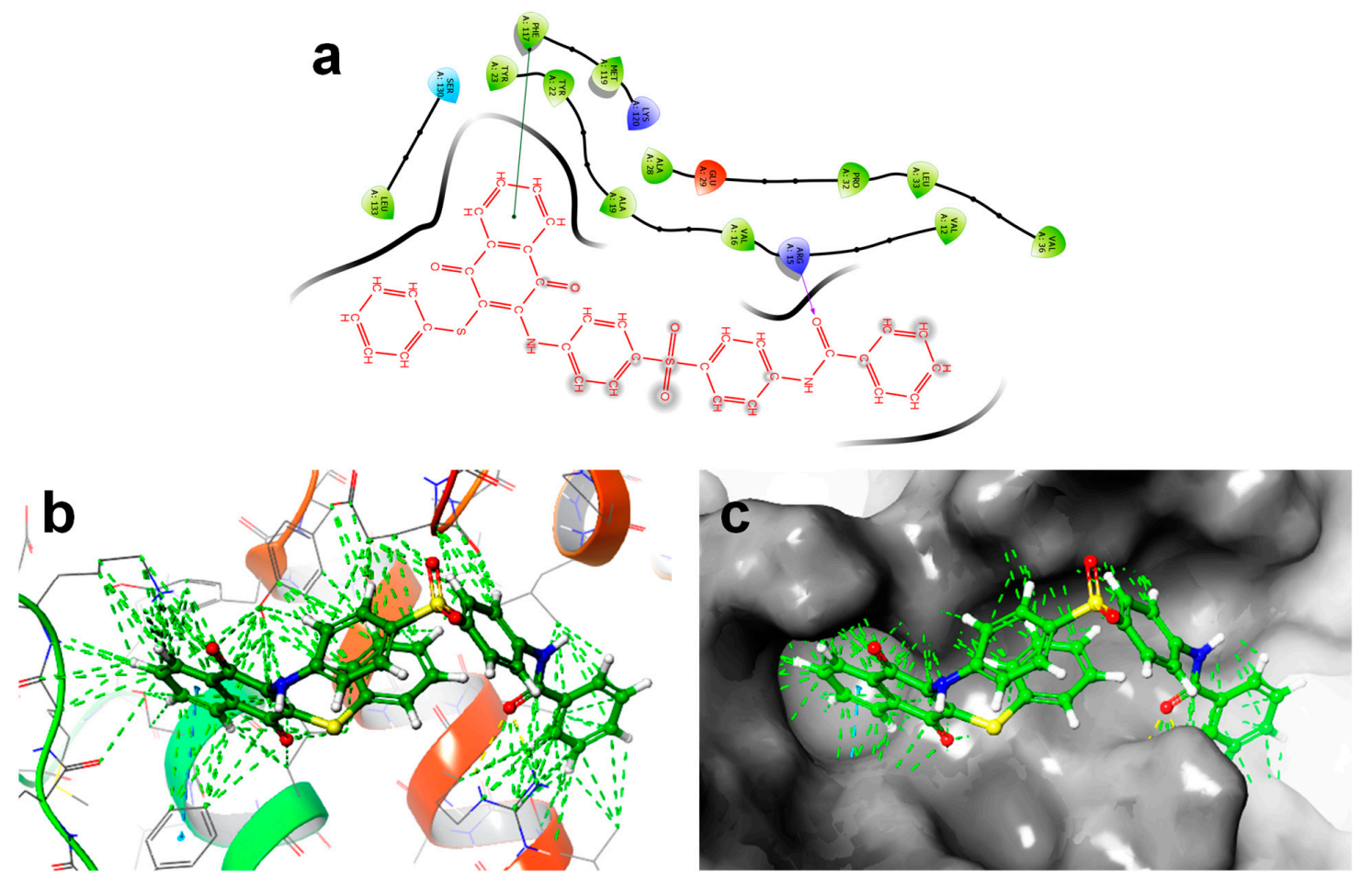

Figure 6. (a) $2 \mathrm{D}$ docking interaction of $5 \mathbf{a}$ with the active site of 3CW0. (b) 3D docking of $5 \mathbf{a}$ $(\mathrm{S}=-2.636 \mathrm{kcal} / \mathrm{mol})$ in the active site of $3 \mathrm{CW0}$. (c) Docking packing representation of $5 \mathbf{a}$ with suitable binding pockets of $3 \mathrm{CW} 0$.

\subsubsection{Electrochemical Study}

An electrochemical study is a convenient tool for characterizing the redox-active molecules [21]. First, $\mathrm{CV}$ for the selected naphthoquinones $\mathbf{5 a}, \mathbf{5} \mathbf{f}$ and $\mathbf{5 x}$ was performed in acetonitrile $\left(\mathrm{CH}_{3} \mathrm{CN}+\right.$ $\left.\mathrm{Bu}_{4} \mathrm{NBF}_{4}, 0.1 \mathrm{~mol} \mathrm{~L}{ }^{-1}\right)$. Cathodic and anodic peak currents were measured at a scan rate of $100 \mathrm{mV}$ $\mathrm{s}^{-1}$ with reference to the $\mathrm{Ag} / \mathrm{Ag}^{+}$electrode (non-aqueous), and the reduction-oxidation potential $\left(E_{\text {redox }}\right.$ values, $\left(E_{p c}+E_{p a}\right) / 2$ were determined using the midpoint of the peak potentials. The $C V$ of $\mathbf{5 a}$ is presented in Figure 7 and comprises two reduction and oxidation peaks. Similar redox peaks were observed for compounds $\mathbf{5 f}$ and $\mathbf{5 x}$ (Figures S1 and S2). The electrochemical measurements for each compound are shown in Table 3. The reduction order was established by comparing the first reduction potentials (Table 3, Column 6). Based on the redox potentials, the reduction potentials of the compounds are in the following order: $5 a>5 f>5 x$. Hence, $\mathrm{CV}$ analysis provided insight into the valuable relationship between MIC value and $E_{\text {redox }}$. The compounds with less negative $E_{\text {redox }}$ values represented more active antibacterial agents. Here, 5 a showed less negative potential and exhibited a better MIC value. The obtained antibacterial activity and redox potentials of $\mathbf{5 a}, \mathbf{5} \mathbf{f}$ and $\mathbf{5 x}$ were correlated with their order of activity. Therefore, these results clearly suggest that redox behaviour is a significant factor in determining the antibacterial activity of naphthoquinones [22]. 
Table 3. The major electrochemical parameters of selected naphthoquinones ( $\mathrm{c}=1 \mathrm{mmol} / \mathrm{L})$, using CV on $\mathrm{GCE}$, in $\mathrm{CH}_{3} \mathrm{CN} / \mathrm{Bu}_{4} \mathrm{NBF}_{4}, 0.1 \mathrm{~mol} / \mathrm{L}, v=100 \mathrm{mV} \mathrm{s}^{-1}$.

\begin{tabular}{cccccc}
\hline Compound & $\mathbf{E p a}_{\mathbf{1}}(\mathbf{V})$ & $\mathrm{Epa}_{\mathbf{2}}(\mathbf{V})$ & $\mathrm{Epc}_{\mathbf{1}}(\mathrm{V})$ & $\mathrm{Epc}_{\mathbf{2}}(\mathrm{V})$ & $\mathrm{E}_{\text {redox }}(\mathrm{V})$ \\
\hline $\mathbf{5 a}$ & -1.111 & -1.598 & -1.279 & -1.647 & -1.194 \\
$\mathbf{5 f}$ & -1.137 & -1.545 & -1.254 & -1.642 & -1.195 \\
$\mathbf{5 x}$ & -1.413 & -1.533 & -1.283 & -1.614 & -1.348 \\
\hline
\end{tabular}

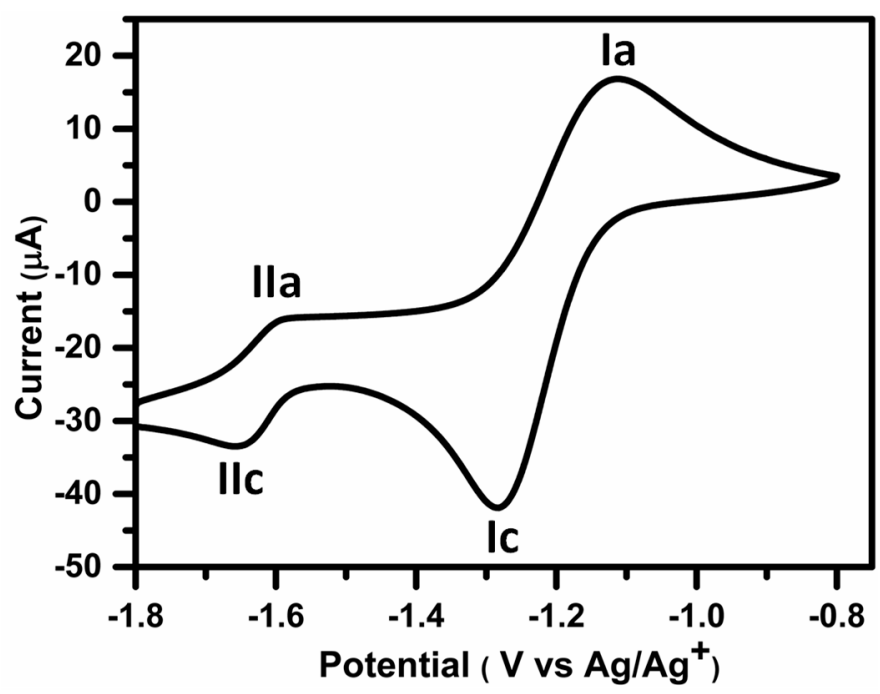

Figure 7. Cyclic voltammetry of $5 \mathrm{a}(1 \mathrm{mM})$ in $\mathrm{CH}_{3} \mathrm{CN}+\mathrm{Bu}_{4} \mathrm{NBF}_{4}(0.1 \mathrm{M})$ on glassy carbon electrode (GCE) with cathodic direction, potential range: $-0.8 \mathrm{~V}$ up to $-2.0 \mathrm{~V}, v=0.1 \mathrm{~V} \mathrm{~s}^{-1}$.

\section{Experimental}

\subsection{Chemistry}

The chemicals, synthetic methods and instruments used for this investigation were the same as those in an earlier study. Please refer to our previous report [16] for the structural characterization of the synthesized naphthoquinones (3-5aa).

\subsection{In Vitro Antibacterial Activity}

Antibacterial activity of the tested samples (3-5aa) was determined by the MIC method. The standard strains were obtained from American type culture collection (ATCC), Korean collection type culture (KCTC) and Korean Agricultural Culture Collection (KACC). In detail, pre-activated (sub-cultured in fresh Luria-Bertani Broth medium (BD Difco ${ }^{\mathrm{TM}}$, Houston, TX, USA) at $37^{\circ} \mathrm{C}$ under shaking conditions (220 rpm) in an incubator overnight) S. aureus (ATCC 23235), L. monocytogenes (ATCC 19111), E. coli (KCTC 2571), P. aeruginosa (KACC 10259) and K. pneumoniae (ATCC BAA-2342) were inoculated separately in $5 \mathrm{~mL}$ of LB liquid medium and incubated at $37^{\circ} \mathrm{C}$ until the log growth phase was achieved (optical density, $\mathrm{OD}_{600}$ value $~ 0.6$ ). After incubation, the bacterial cell culture was centrifuged (8000 rpm for $10 \mathrm{~min}$.) and washed with a phosphate-buffered solution (PBS). The cell pellets were suspended in PBS solution to attain a final density of $10^{6}$ cells $/ \mathrm{mL}$ (standardized spectrophotometrically $\mathrm{OD}_{540} \sim 1.0$ ). Bacterial suspensions in Luria-Bertani Broth medium at initial inoculums of $10^{6}$ cells $/ \mathrm{mL}$ were added to polystyrene 96-well plates and exposed to the synthesized naphthoquinones (3-5aa) at sufficient concentrations (range: $0.05 \mu \mathrm{g} / \mathrm{mL}$ to $1000 \mu \mathrm{g} / \mathrm{mL}$ ) for $24 \mathrm{~h}$ at $37^{\circ} \mathrm{C}$. Dimethyl sulfoxide (DMSO) was used as a solvent. The MIC was the lowest drug concentration at which observable bacterial growth was inhibited. Commercially available streptomycin was used as a reference compound. All tests were performed in triplicate [23]. 


\subsection{Bactericidal Time-Kill Kinetic Study}

E. coli were seeded for $12 \mathrm{~h}$ and diluted to 1:10000 in Mueller Hinton Broth (MHB) medium. The cells were cultured at $37^{\circ} \mathrm{C}$ with aeration of $225 \mathrm{rpm}$ for $2 \mathrm{~h}$. Compounds $5 \mathbf{a}, \mathbf{5 f}$ and $5 \mathbf{x}$ were treated with $E$. coli at respective MIC values in culture tubes at $37^{\circ} \mathrm{C}$ at $225 \mathrm{rpm}$. At regular pauses, $100 \mu \mathrm{L}$ of bacterial solution was placed in a 96-well plate, centrifuged for 3 min and resuspended in $100 \mu \mathrm{L}$ of $1 \times$ PBS. Serially diluted bacterial suspensions were placed and nursed on Mueller Hinton Agar (MHA) plates at $37^{\circ} \mathrm{C}$ overnight. Finally, any colonies that formed were counted, and CFU per $\mathrm{mL}$ was calculated. All experiments were performed in triplicate [24].

Analysis of Minimum Bactericidal Concentration (MBC)

By subculture method, MBC was determined. At first, the concentration of samples $\mathbf{5 a}, \mathbf{5} \mathbf{f}$ and $\mathbf{5 x}$ were prepared at their respective MIC concentrations. Next, the samples inoculated and incubated onto agar for $24 \mathrm{~h}$ in Petri plates at $37^{\circ} \mathrm{C}$. MBC was calculated as $99.9 \%$ of the early bacterial inoculum was killed by the lowermost concentration of samples $(<0.01 \%$ of survivors $)$. All experiments were carried out in triplicate [25].

\subsection{Naphthoquinone-Generated ROS Detection}

$2^{\prime}, 7^{\prime}$-Dichlorofluorescein-diacetate (DCFH-DA), a fluorescent dye, was used to measure the generation of ROS [26]. E. coli was incubated, washed with PBS and resuspended in PBS buffer (pH-7.2). Bacterial cells were stained with $10 \mu \mathrm{M}$ DCFH-DA for $30 \mathrm{~min}$ at $37{ }^{\circ} \mathrm{C}$ in the dark. The cells were then washed with double distilled water to remove the unreacted DCFH-DA. Next, DCFH-DA-treated bacterial cells were incubated with compounds $\mathbf{5 a}, \mathbf{5 f}$ and $\mathbf{5 x}(15.6 \mu \mathrm{g} / \mathrm{mL}, 31.25 \mu \mathrm{g} / \mathrm{mL}$ and $31.25 \mu \mathrm{g} / \mathrm{mL}$, respectively) for $4 \mathrm{~h}$. Finally, the ROS generation of samples incubated with E. coli was determined by fluorescence microscopy (LSM 510 META-Carl Zeiss, Jena, Germany) installed at the Center for University-Wide Research Facilities (CURF) at Chonbuk National University (CBNU, Jeollabuk-do, Republic of Korea). The excitation-emission wavelengths were fixed at $488 \mathrm{~nm}$ and $535 \mathrm{~nm}$, respectively [27]. Streptomycin was used as a positive control $(1.90 \mu \mathrm{g} / \mathrm{mL})$.

\subsection{Apoptosis Determination by Annexin V-FITC/PI Assay}

After treatment with compounds $\mathbf{5 a}, \mathbf{5} \mathbf{f}$ and $\mathbf{5 x}$, the infected E. coli cells were assessed with the FITC-Annexin V/PI using a BD FACSCalibur flow cytometer (San Jose, California, USA). Compounds with corresponding MICs were treated with bacterial solution $\left(1 \times 10^{7}\right)$ for $12 \mathrm{~h}$. After incubation, to remove any excess of bacterial culture, the bacterial solution was centrifuged and washed with PBS ( $\mathrm{pH}$ 7.2). The accumulated cell pellet was resuspended in Annexin V binding buffer. The staining protocol was performed according to the manufacturer's instructions. Finally, the stained cells were counted using a BD FACSCalibur flow cytometer (San Jose, California, USA). The acquired data were isolated using FlowJo 10.0.7 software (Treestar Inc, Ashland, OR, US) [28].

\subsection{In Silico Molecular Docking Study}

An in silico docking study was performed to understand the binding mechanism of 5a, using the crystal structure of E. coli DmsD (PDB ID: 3CW0) [29]. Prior to molecular docking, the crystal structure of the E. coli receptor was prepared using the protein preparation wizard in Schrödinger Maestro (version 8.5, Schrödinger, LLC, New York, USA). The crystal structure was transferred from the protein data bank (PDB), and the chemical structures of the compounds were drawn using ChemDraw Professional 15.1. The docking study was performed using an Extra Precision (XP) mode docking protocol. The XP GS score was calculated to evaluate the docking output, and PyMOL was used to determine the binding mode [30]. 


\subsection{Electrochemical Study}

The electrochemical experiment was performed on a potentiostat/galvanostat/ZRA Gamry model REF600 device with a three-electrode system. Glassy carbon, platinum (Pt) wire and Ag/Agcl (non-aqueous) electrodes were employed as working, counter and reference electrodes, respectively. Tetrabutylammonium tetrafluoroborate $(0.1 \mathrm{M})$ in $\mathrm{CH}_{3} \mathrm{CN}$ was used as a supporting electrolyte. $\mathrm{CV}$ was run at $100 \mathrm{mV} \mathrm{s}^{-1}$, and scanning of the window potential started toward the positive and then the negative directions. Compounds $\mathbf{5 a}, \mathbf{5} \mathbf{f}$ and $\mathbf{5 x}$ were dissolved in DMSO at fixed concentrations of $1 \mathrm{mM}$ and were added to the supporting electrolyte $(12 \mathrm{~mL})$. The $\mathrm{CV}$ measurement was carried out in a nitrogen environment [31].

\section{Conclusions}

In summary, this study effectively demonstrated successful synthesis of naphthoquinone derivatives and in vitro antimicrobial evaluation of the compounds. A mechanism of action for naphthoquinone derivatives to E. coli that involves bacterial membrane binding was confirmed by intracellular ROS generation, apoptosis induced effects and a bactericidal time-killing study. In addition, molecular modelling and an electrochemical study were established to support the mechanism of antibacterial activity. Thus, the obtained results indicate that additional studies are needed to determine the clinical applications of these synthesized compounds as potent antibacterial candidates for $E$. coli. These compounds could be applied in the future to target and control E. coli infections, which is one of the most predominant microorganisms in hospitalized infections.

Supplementary Materials: The following are available online at http://www.mdpi.com/1420-3049/24/7/1437/s1. Figure S1 and Figure S2: Electrochemical study of compounds $\mathbf{5 f}$ and $\mathbf{5 x}$, respectively.

Author Contributions: P.R.; synthesized all the compounds, carried out the electrochemical study and wrote the entire manuscript, S.S.; carried out antibacterial data analysis, D.P.; carried out the in silico docking study, A.R.K.; research discussion and suggestion, D.J.Y.; supervision of the work.

Acknowledgments: This work was supported by grants from the Medical Research Center Program (NRF-2017R1A5A2015061) through the National Research Foundation (NRF), which is funded by the Korean government (MSIP). This work was supported by the Korea Institute of Energy Technology Evaluation and Planning (KETEP) and the Ministry of Trade, Industry \& Energy (MOTIE) of the Republic of Korea (No. 20184030202210).

Conflicts of Interest: The authors declare no conflict of interest.

\section{References}

1. Ma, S.; Ma, S. The Development of FtsZ Inhibitors as Potential Antibacterial Agents. ChemMedChem 2012, 7, 1161-1172. [CrossRef]

2. Liu, C.; Shen, G.-N.; Luo, Y.-H.; Piao, X.-J; Jiang, X.-Y.; Meng, L.-Q.; Wang, Y.; Zhang, Y.; Wang, J.-R.; Wang, H.; et al. Novel 1,4-naphthoquinone derivatives induce apoptosis via ROS-mediated p38/MAPK, Akt and STAT3 signaling in human hepatoma Hep3B cells. Int. J. Biochem. Cell Biol. 2018, 96, 9-19. [CrossRef] [PubMed]

3. Li, K.; Wang, B.; Zheng, L.; Yang, K.; Li, Y.; Hu, M.; He, D. Target ROS to induce apoptosis and cell cycle arrest by 5,7-dimethoxy-1,4-naphthoquinone derivative. Bioorg. Med. Chem. Lett. 2018, 28, 273-277. [CrossRef] [PubMed]

4. Fernando de Carvalho da, S.; Vitor Francisco, F. Natural Naphthoquinones with Great Importance in Medicinal Chemistry. Curr. Org. Synth. 2016, 13, 334-371. [CrossRef]

5. Rho, Y.S.; Kim, S.Y.; Kim, W.J.; Yun, Y.K.; Sin, H.S.; Yoo, D.J. Convenient Syntheses of Daunomycinone7-D-Glucuronides and Doxorubicinone-7-D-Glucuronides. Synth. Commun. 2004, 34, 3497-3511. [CrossRef]

6. Ma, W.-D.; Zou, Y.-P.; Wang, P.; Yao, X.-H.; Sun, Y.; Duan, M.-H.; Fu, Y.-J; Yu, B. Chimaphilin induces apoptosis in human breast cancer MCF-7 cells through a ROS-mediated mitochondrial pathway. Food Chem. Toxicol. 2014, 70, 1-8. [CrossRef]

7. Wellington, K.W. Understanding cancer and the anticancer activities of naphthoquinones-A review. RSC Adv. 2015, 5, 20309-20338. [CrossRef] 
8. Novais, J.S.; Campos, V.R.; Silva, A.C.J.A.; de Souza, M.C.B.V.; Ferreira, V.F.; Keller, V.G.L.; Ferreira, M.O.; Dias, F.R.F.; Vitorino, M.I.; Sathler, P.C.; et al. Synthesis and antimicrobial evaluation of promising 7-arylamino-5,8-dioxo-5,8-dihydroisoquinoline-4-carboxylates and their halogenated amino compounds for treating Gram-negative bacterial infections. RSC Adv. 2017, 7, 18311-18320. [CrossRef]

9. Manickam, M.; Boggu, P.R.; Cho, J.; Nam, Y.J.; Lee, S.J.; Jung, S.-H. Investigation of chemical reactivity of 2-alkoxy-1,4-naphthoquinones and their anticancer activity. Bioorg. Med. Chem. Lett. 2018, 28, 2023-2028. [CrossRef]

10. Pullella, G.A.; Wild, D.A.; Nealon, G.L.; Elyashberg, M.; Piggott, M.J. What Is the Structure of the Antitubercular Natural Product Eucapsitrione? J. Org. Chem. 2017, 82, 7287-7299. [CrossRef]

11. Lanfranchi, D.A.; Cesar-Rodo, E.; Bertrand, B.; Huang, H.H.; Day, L.; Johann, L.; Elhabiri, M.; Becker, K.; Williams, D.L.; Davioud-Charvet, E. Synthesis and biological evaluation of 1,4-naphthoquinones and quinoline-5,8-diones as antimalarial and schistosomicidal agents. Org. Biomol. Chem. 2012, 10, 6375-6387. [CrossRef]

12. Lara, L.S.; Moreira, C.S.; Calvet, C.M.; Lechuga, G.C.; Souza, R.S.; Bourguignon, S.C.; Ferreira, V.F.; Rocha, D.; Pereira, M.C.S. Efficacy of 2-hydroxy-3-phenylsulfanylmethyl-[1,4]-naphthoquinone derivatives against different Trypanosoma cruzi discrete type units: Identification of a promising hit compound. Eur. J. Med. Chem. 2018, 144, 572-581. [CrossRef]

13. Klaus, V.; Hartmann, T.; Gambini, J.; Graf, P.; Stahl, W.; Hartwig, A.; Klotz, L.-O. 1,4-Naphthoquinones as inducers of oxidative damage and stress signaling in HaCaT human keratinocytes. Arch. Biochem. Biophys. 2010, 496, 93-100. [CrossRef]

14. Ravichandiran, P.; Jegan, A.; Premnath, D.; Periasamy, V.S.; Muthusubramanian, S.; Vasanthkumar, S. Synthesis, molecular docking and cytotoxicity evaluation of novel 2-(4-amino-benzosulfonyl)-5Hbenzo[b]carbazole-6,11-dione derivatives as histone deacetylase (HDAC8) inhibitors. Bioorg. Chem. 2014, 53, 24-36. [CrossRef]

15. Ravichandiran, P.; Premnath, D.; Vasanthkumar, S. Synthesis, molecular docking and antibacterial evaluation of 2-(4-(4-aminophenylsulfonyl)phenylamino)-3-(thiophen-2-ylthio)naphthalene-1,4-dione derivatives. Front. Chem. Sci. Eng. 2015, 9, 46-56. [CrossRef]

16. Ravichandiran, P.; Subramaniyan, S.A.; Kim, S.-Y.; Kim, J.-S.; Park, B.-H.; Shim, K.S.; Yoo, D.J. Synthesis and anticancer evaluation of novel 1,4-naphthoquinone derivatives containing a phenylamino-sulfanyl moiety. ChemMedChem 2019, 14, 532-544. [CrossRef]

17. Stratton, C.W.; Weeks, L.S.; Aldridge, K.E. Comparison of kill-kinetic studies with agar and broth microdilution methods for determination of antimicrobial activity of selected agents against members of the Bacteroides fragilis group. J. Clin. Microbiol. 1987, 25, 645-649.

18. Weil, O.; Berche, P. The cholera epidemic in Ecuador: towards an endemic in Latin America. Revue d'epidemiologie et de sante publique 1992, 40, 145-155.

19. Liang, W.; Cai, A.; Chen, G.; Xi, H.; Wu, X.; Cui, J.; Zhang, K.; Zhao, X.; Yu, J.; Wei, B.; et al. Shikonin induces mitochondria-mediated apoptosis and enhances chemotherapeutic sensitivity of gastric cancer through reactive oxygen species. Sci. Rep. 2016, 6, 38267. [CrossRef]

20. Pires, D.E.; Blundell, T.L.; Ascher, D.B. pkCSM: Predicting Small-Molecule Pharmacokinetic and Toxicity Properties Using Graph-Based Signatures. J. Med. Chem. 2015, 58, 4066-4072. [CrossRef]

21. De Paiva, Y.G.; da Rocha Ferreira, F.; Silva, T.L.; Labbe, E.; Buriez, O.; Amatore, C.; Fonseca Goulart, M.O. Electrochemically driven supramolecular interaction of quinones and ferrocifens: an example of redox activation of bioactive compounds. Curr. Top. Med. Chem. 2015, 15, 136-162. [CrossRef]

22. Valderrama, J.A.; Andrea Ibacache, J.; Arancibia, V.; Rodriguez, J.; Theoduloz, C. Studies on quinones. Part 45: Novel 7-aminoisoquinoline-5,8-quinone derivatives with antitumor properties on cancer cell lines. Bioorg. Med. Chem. 2009, 17, 2894-2901.

23. Janeczko, M.; Demchuk, O.M.; Strzelecka, D.; Kubiński, K.; Masłyk, M. New family of antimicrobial agents derived from 1,4-naphthoquinone. Eur. J. Med. Chem. 2016, 124, 1019-1025. [CrossRef]

24. Chu, W.C.; Bai, P.Y.; Yang, Z.Q.; Cui, D.Y.; Hua, Y.G.; Yang, Y.; Yang, Q.Q.; Zhang, E.; Qin, S. Synthesis and antibacterial evaluation of novel cationic chalcone derivatives possessing broad spectrum antibacterial activity. Eur. J. Med. Chem. 2018, 143, 905-921. [CrossRef] 
25. Dongmo, N.A.; Nganso, D.Y.O.; Nkwensoua, T.E.; Boda, A.M.; Voundi, O.S.; Etoafa, F.X.; Nyasse, S. Nyasse In-vitro Testing of Extracts and Fractions From two Cameroonian Medicinal Plants on Bacteria Gastroenteritis. Am. J. Phytomed. Clin. Ther. 2015, 3, 575-588.

26. Eruslanov, E.; Kusmartsev, S. Identification of ROS using oxidized DCFDA and flow-cytometry. Methods Mol. Biol. 2010, 594, 57-72.

27. Koontz, J.; Kontrogianni-Konstantopoulos, A. Competition through dimerization between antiapoptotic and proapoptotic HS-1-associated protein X-1 (Hax-1). J. Biol. Chem. 2014, 289, 3468-3477. [CrossRef]

28. Sheet, S.; Vinothkannan, M.; Balasubramaniam, S.; Subramaniyan, S.A.; Acharya, S.; Lee, Y.S. Highly Flexible Electrospun Hybrid (Polyurethane/Dextran/Pyocyanin) Membrane for Antibacterial Activity via Generation of Oxidative Stress. ACS Omega 2018, 3, 14551-14561. [CrossRef]

29. Ramasamy, S.K.; Clemons, W.M., Jr. Structure of the twin-arginine signal-binding protein DmsD from Escherichia coli. Acta Crystallogr. Sect. F Struct. Biol. Cryst. Commun. 2009, 65, 746-750. [CrossRef]

30. Friesner, R.A.; Murphy, R.B.; Repasky, M.P.; Frye, L.L.; Greenwood, J.R.; Halgren, T.A.; Sanschagrin, P.C.; Mainz, D.T. Extra precision glide: docking and scoring incorporating a model of hydrophobic enclosure for protein-ligand complexes. J. Med. Chem. 2006, 49, 6177-6196. [CrossRef]

31. Hillard, E.A.; de Abreu, F.C.; Ferreira, D.C.M.; Jaouen, G.; Goulart, M.O.F.; Amatore, C. Electrochemical parameters and techniques in drug development, with an emphasis on quinones and related compounds. Chem. Commun. 2008, 2612-2628. [CrossRef]

Sample Availability: Samples of the compounds 3-5aa are available from the authors.

(C) 2019 by the authors. Licensee MDPI, Basel, Switzerland. This article is an open access article distributed under the terms and conditions of the Creative Commons Attribution (CC BY) license (http://creativecommons.org/licenses/by/4.0/). 